\title{
THREATS AND OPPORTUNITIES FOR GLOBAL FOOD COMPANIES: IDENTIFYING SOCIAL AND ENVIRONMENTAL ISSUES IN FOOD VALUE CHAIN TO CREATE SHARED VALUE
}

\author{
Ishak Kherchi $^{1}$
}

date of paper receipt:

10.01.2020.

Case Report date of sending to review:

12.01.2020.

doi:10.2478/eoik-2020-0004 date of review receipt:

20.01.2020.

UDK:

663/664:[658.8.012.12:631.147

${ }^{1}$ Faculty of Economic, Business and Management Science University of Hassiba Benbouali, Chlef, Algeria Laboratory of development of the competitiveness of algerian SME in substitute industries

\section{ABSTRACT}

\section{Purpose:}

This paper aims to identify social and environmental issues in value chain of food companies to create shared value. We provided most affecting social and environmental issues on businesses companies value chain; in addition to that we provided some solutions to social and environmental problems based on shared value concept.

Design/methodology/approach:

The authors provide a proposed approach based on the specificity of problems and issues in agricultural and global food companies. The objective is to identify environmental and social issues in food value chain in order to invest in these issues to create shared value.

Findings:

We found that every primary and secondary activity within food value chain is characterized by some social and environmental problems. We analyzed these social and environmental issues in every single activity. In addition to that we provided proposed solutions to these social and environmental issues using shared value concept in every single activity within company value chain.

\section{Research limitations/implications:}

This research paper determines social and environmental issues in value chain for food global companies; however, more research is needed to find other social and environmental issues in other sectors.

\section{Practical implications:}

This overview may help and give ideas to owners and managers of food companies to rethink their overall value chain by detecting environmental and social issues and used shared value concept to turn these environmental and social issues into a business opportunity.

Originality/value:

A unique view of value chain analyzed by identifying environmental and social issues using shared value concept.

\section{Keywords:}

Social and environmental issues, value chain, creating shared value, agricultural sector, food companies. 


\section{INTRODUCTION}

Most global companies in food industry receive a lot of pressure for the negative output of their activity, despite the effort of food companies to hold back their negative impact on environment and society through corporate social responsibility; the environmental and social impact of food companies in food industry is still huge and considering as a business threat that need to be addressed from another angles to turn it into a business opportunity by providing practical solutions.

Global food companies need to analyze its own value chain in order to identify every environmental or social problem in every single activity in order to visualize a practical solution. In this context the concept of shared value creation is one of the most searched topics in business management recently, because shared value concept provides solutions to the negative impact of companies' activity on society and environment. So the question is: How to use shared value concept to identify environmental and social issues in the value chain for global food companies, and how using shared value concept could solve these issues creating value for business, society and environment?

\section{LITERATURE REVIEW}

We provide literature review that coverage our study objectives by providing a comprehensive table explaining what have been done within the subject. In the literature there seems to be no general agreements to determine the main social and environmental issues within companies' value chain, some studies focused only on social issues while other studies focused on environmental issues as we see in table1.

Table 1. Comprehensive table for literature review

\begin{tabular}{|c|c|}
\hline The study & Findings \\
\hline Ranganathan.J (1998) & $\begin{array}{l}\text { Ranganathan.J (1998) suggests four issues for corporate environment: materials use, } \\
\text { energy consumption, non product output, pollutant releases }\end{array}$ \\
\hline Panwar.R,Hansen.E.N (2009) & $\begin{array}{l}\text { Panwar.R, Hansen.E.N (2009) mentioned six social and environmental issues USA } \\
\text { face; social issues: encourage public scrutiny on environmental, and land management } \\
\text { practices. Invest in surrounding communities, promote responsible consumption } \\
\text { among consumers. Stem declining employment in the sector. Engage with the } \\
\text { surrounding communities. Improve industry's public image. While environmental } \\
\text { issues are: promoting sustainable forestry, Increase the use of renewable resources, } \\
\text { Adopt environmentally sound purchasing policies, Mitigate global warming, reduce } \\
\text { overall energy consumption, Improve waste management }\end{array}$ \\
\hline Godfray et al., (2010) & $\begin{array}{l}\text { Godfray et al., (2010) mentioned that poverty, food insecurity, climate change and } \\
\text { biodiversity are the primary social and environmental challenges faced by the global } \\
\text { community }\end{array}$ \\
\hline $\begin{array}{l}\text { Riisgaard.L, Bolwig.S, Ponte.S, } \\
\text { Toit.A, Halberg.N, Frank } \\
\text { Matose.F (2010) }\end{array}$ & $\begin{array}{l}\text { Riisgaard.L, Bolwig.S, Ponte.S, Toit.A, Halberg.N, Frank Matose.F (2010) mentioned } \\
\text { poverty, gender, labor and environmental concerns as the main concerns into value- } \\
\text { chain analysis }\end{array}$ \\
\hline $\begin{array}{l}\text { L.F. Henriksen, L. Riisgaard, } \\
\text { S. Ponte, F. Hartwich, P. } \\
\text { Kormawa (2010) }\end{array}$ & $\begin{array}{l}\text { L.F. Henriksen, L. Riisgaard, S. Ponte, F. Hartwich, P. Kormawa (2010) provide } 9 \\
\text { Common environmental issues: Land used for production and processing, efficiency } \\
\text { of energy use, Sources of energy, water use and contamination, Quantity and quality } \\
\text { of chemicals, Waste production and management, possible effects of production and } \\
\text { processing on ecosystems, Pollution potentials such as acidification, euthrophication } \\
\text { and others and Greenhouse gas emissions. }\end{array}$ \\
\hline Torres \& van Seters (2016) & $\begin{array}{l}\text { Torres \& van Seters (2016) found that poor access to key inputs, lack of secure } \\
\text { land rights, water access limitations under erratic weather and poor development } \\
\text { of irrigation, weak production technologies are the main environmental issues for } \\
\text { business companies }\end{array}$ \\
\hline
\end{tabular}

Source: authors (2020) based on previous studies 
(Ranganathan.J, 1998) suggests four issues for corporate environment: materials use, energy consumption, non product output, pollutant releases. (Panwar.R, Hansen.E.N, 2009) mentioned six social and environmental issues however he did not provide any possible solution for these social and environmental issues.

(Godfray et al, 2010) mentioned some social and environmental issues with no separation between these issues. (Riisgaard.L, 2010) mentioned four issues: poverty, gender, labor and environmental concerns as the main concerns into value-chain analysis. (L.F. Henriksen, L. Riisgaard, S. Ponte, F. Hartwich and P. Kormawa, 2010) provide 9 Common environmental issues to be approached through development projects and which could be targeted via value chain interventions.

A recent review of the literature on this topic; (Torres \& van Seters, 2016) provide five environmental issues for business companies with no attention to social issues or any possible solution for both issues.

We clearly see that all of these previous studies were related to global environmental issues, there is no previous studied that analyzed the environmental issues within company value chain.

In addition to that; previous studies focused more on the environmental issues rather than social issues, we could not find any study that analyze social and environmental issues within company value chain. Regarding to the literature we attempt to provide a proposed social and environmental issues within food companies' value chain.

\section{FOOD VALUE CHAIN}

Food value chains (FVCs) comprise all activities required to bring farm products to consumers, including agricultural production, processing, storage, marketing, distribution and consumption (Meybeck.A \& Redfern.S, 2016)

Value chains involve many actors that influence the way in which food is produced, processed, distributed, marketed and consumed. The term "food value chain" describes the full range of activities required to bring a food product from conception, through the various phases of production, to delivery to end-consumers and eventually disposal following use (Kraemer et al, 2016).

Food value chains also represent a business model in which producers and buyers of agricultural products form strategic alliances with other supply chain actors, such as aggregators, processors, distributors, retailers, and consumers, to enhance financial returns through product differentiation that advances social or environmental value (Diamond et al, 2014). Food value chain represents "the system of organizations, people, and activities involved in moving food from its producer (usually the farmer) to the consumer (Beretta, C. Stoessel, F., Baier, U and Hellweg, S. 2013). Private companies have attempted to respond to environmental issues. Nowadays, the economic performance of business is often seen in conjunction with its social and environmental performances.

\section{WHY WE NEED TO IDENTIFY SOCIAL AND ENVIRONMENTAL ISSUES IN FOOD VALUE CHAIN}

The United Nations department of economic and social affairs pointed that the waste we facing now is $30-40 \%$ in food product, in developing countries the food produced never reach to consumer while in developed countries a high level of waste is made (Giovannucci. D et al 2012).

It is also estimated that number of people will increase by 2050 reaching 9.3 billion people especially in countries which face a lot of social and environmental issues such as: poverty, lack access to food, overweight, malnutrition (Revision of World Population Prospects, 2010)

Food production should increase by $50 \%$ to feed the world population by 2050 , at the same time agricultural land that is appropriate for food production continue to decrease due to a lot of environmental issues such as: soil degradation and the quantity of available water (FAO, IFAD, UNICEF, WFP and WHO, 2017) 
In addition to that, it is estimated that 2 billion people suffer from micronutrients deficiency, this social issue will affect small children, and in all over the world 159 million children under 5 years had growth issues (UNEP, 2016)

It is estimated that 800 million people suffer from micronutrient issues and hunger especially in developing countries and low income areas. The human consequences are real but incalculable. Eliminating global under nutrition by 2030 faces huge challenges. This reflects in part the complexity of factors involved besides food-insufficiency, such as poor quality water, sanitation and hygiene, inadequate caring practices, and disease. The world need an urgent initiatives to address these social and environmental issues by providing food, health care, clean water and sanitation, and women's empowerment, agriculture is the main source of livelihoods, employing $60 \%$ of the total workforce (Maestre.M.A, Poole.N.B, Henson.S.C, 2017).

The developmental, economic, social, and medical impacts of the global burden of malnutrition are serious and lasting, for individuals and their families, for communities and for countries (World health organization, 2018).

In field of Biology, Environment and Chemistry; researchers a studied the effects of agricultural practices on environment; they found increasing of harm on environment with every aspect was more and more than renewability capacity of environment therefore the environment started to deterioration (ÖNDER.M, CEYHAN.E and KAHRAMAN.A,2011).

The food and agriculture organization of the United Nations and the international water management institute on behalf of the water land and ecosystems research program found that high-income countries and emerging economies has a high level of agricultural pollution causing a serious environmental issues (Sagasta.J.M, Zadeh .S.M and Turral.H, 2017).

In this context, a published article in sustainable agriculture reviews done by Bourguet $\mathrm{D}$, Guillemaud T in 2016 found, that various human health related concerns are associated with pesticides, ranging from short term impacts such as headaches and nausea to chronic impacts, such as various cancers, birth defects, infertility, and endocrine disruption (Bourguet D \& Guillemaud $\mathrm{T}$, 2016). The world health organization estimates that acute pesticide poisoning affects 3 million people and accounts for 20,000 unintentional deaths per year, with 99 percent of these fatalities believed to be in developing countries (Dabady.K \& Tulk.P, 2015).

\section{CREATING SHARED VALUE}

Shared value is fundamentally about integrating social and environmental impact into the business and using that integration to drive economic value (Bolanle Deborah Motilewa, E.K. Rowland Worlu, Agboola.G.M and Gberevbie. M.A.C, 2016).

Shared value is also about linking profitability with societal needs. Profiting from improving social outcomes is a marriage that sits uncomfortably with some people; however it is a very effective marriage because the business sustains its involvement due to financial incentive. In the same time It's embedded in core business operations and mobilizes greater resources, whereas donations and community programs come from limited 'budgets' or allocations. In addition to that it's leveraging what the business is good at or has in abundance, which maximizes social impact (Preston.P, 2017). 


\section{THREE APPROACHES ARE IDENTIFIED FOR COMPANIES TO CREATE SHARED VALUE}

There are three pillars of shared value. These pillars include: (Diamond et al, 2014):

1 - Reconceiving products and markets by using innovation and research development to provide a friendly product, or a product that meets unmet needs for the society

2- Redefining productivity in the value chain, by finding ways to reduce Co 2 emissions, water use, energy and electricity consumption, support employees.

3- Building supportive industry clusters by working with every effective part in business, it means that company need to work and collaborate with others in order to make a collective impact that leads to a shared value creation.

\section{REINFORCING ELEMENTS FOR SHARED VALUE CREATION}

In order to create shared value, companies need reinforcing elements however culture context and strategy affect the balance of these elements: (Ilmarinen.P, 2017):

6-1-Embedding a social purpose:

It aims at answering social issues in a profitable way. The whole social mission should be rooted in the company's culture. A company should concentrate its resources to innovation development, which can assist on solving social problems. Shared value opportunities should be turned into activities. However, this requires a clear social purpose which should be published internally and externally. It should also be included to the core processes, such as strategic planning and budgeting. 6-2- Defined a social need:

Secondly, they all defined a social need; they need to comprehend the original social conditions to be able to change them. With the help of this, a company can divide resources better, develop the business case and recognize capabilities needed inside and outside the company.

6-3-Measuring:

The aim is to provide social and business benefits, which are scalable and measurable. Thus, there is no universal system to measure the results. However, there have been developed three steps for the measuring. The company needs to estimate the value of the business and social issues. This means that if there is a change in social conditions, how it will affect the profits. Next, they need to measure the results in the middle and track the progress. At the end, they need to assess the shared value which is produced and measure the final social and economic benefit.

6-4-Create an optimal innovation structure:

There should be a semiautonomous unit which develops the initiatives. These should be integrated to the core business which then launched them. There should also be a governmental support for the initiatives. It can be for example funding. The company should also use external entrepreneurs who could tackle and solve challenges.

\section{IDENTIFYING SOCIAL AND ENVIRONMENTAL ISSUES IN FOOD VALUE CHAIN TO CREATE SHARED VALUE}

The most important step in creating shared value is to find an environmental or social issues that may generate profit if companies bring solutions with a business model, that's why we trying to identify social and environmental issues in food value chain which look like a business opportunity for companies to achieve profit from solving environmental and social issues and create value for the environment and society.

7-1- Identifying social issues in food value chain:

Improving the value chain requires consideration not only of the environmental issues but also 
social and health issues that's why we should improve nutritional outcomes not just way food is produced, but also how it is processed, distributed, marketed and consumed, a process that is usually referred to as value chain.

As we see in figure 1, food value chain combines primary activities and secondary activities:

7-1-1- Primary activities:

In-bound logistics: there are a lot of social problems within food value chain, if food companies address these social problems; there will be great chance to achieve business value and social value, social problems such as: low productivity and income of the dairy farmers low market access for smallholders, lack of financial services for farmers in rural areas, Lack of technical assistance, low quality farming material, low living conditions of farmers, lack of credit access, poor infrastructure, low education levels among the farmers, poor managerial and entrepreneurial skills.

Operations: In addition to In-bound logistics; there are a lot of social problems within food operations activities such as: micronutrient deficiencies, high levels of sugar, fat and salt in products, low level of fibers and microbial contamination of foods.

Outbound logistics: in addition to In-bound logistics and operations; there are a lot of social problems within outbound logistics that need to be addressed such as: low access to food, low availability of healthy food, poor knowledge for retailers, transportation costs.

Marketing and Sales: marketing and sales activity may create value if food companies would be able to solve some social problems related to this activity such as: poor content of essential nutrients, low access for affordable and nutritional food, poor nutrition information on packaging, poor marketing channels.

Service: service activity may create value if food companies would be able to solve some social problems related to this activity such as: weak supporting service for smallholders, lack of Information available to consumers, lack of Awareness of food nutritive value and eating practices, lack of cooking skills.

7-1-2- Secondary activities:

Procurement: there are a lot of social problems within food value chain, if food companies address these social problems; there will be great chance to achieve business value and social value, social problems such as: low security material for workers, low quality equipment, work accident, lack of safety equipment.

Human resource Development: some social problems such as: lack of employment opportunity, Farmers' living standard, the focus on holding down wage levels, reducing benefits.

Technological development: some social problems that hold companies to grow such as: low level of research activity, low level of research skills for an innovation, lack of proper personal assets. Infrastructure: lack access for information, low managerial and entrepreneurial skills. 
Figure 1 Identifying social issues in food value chain

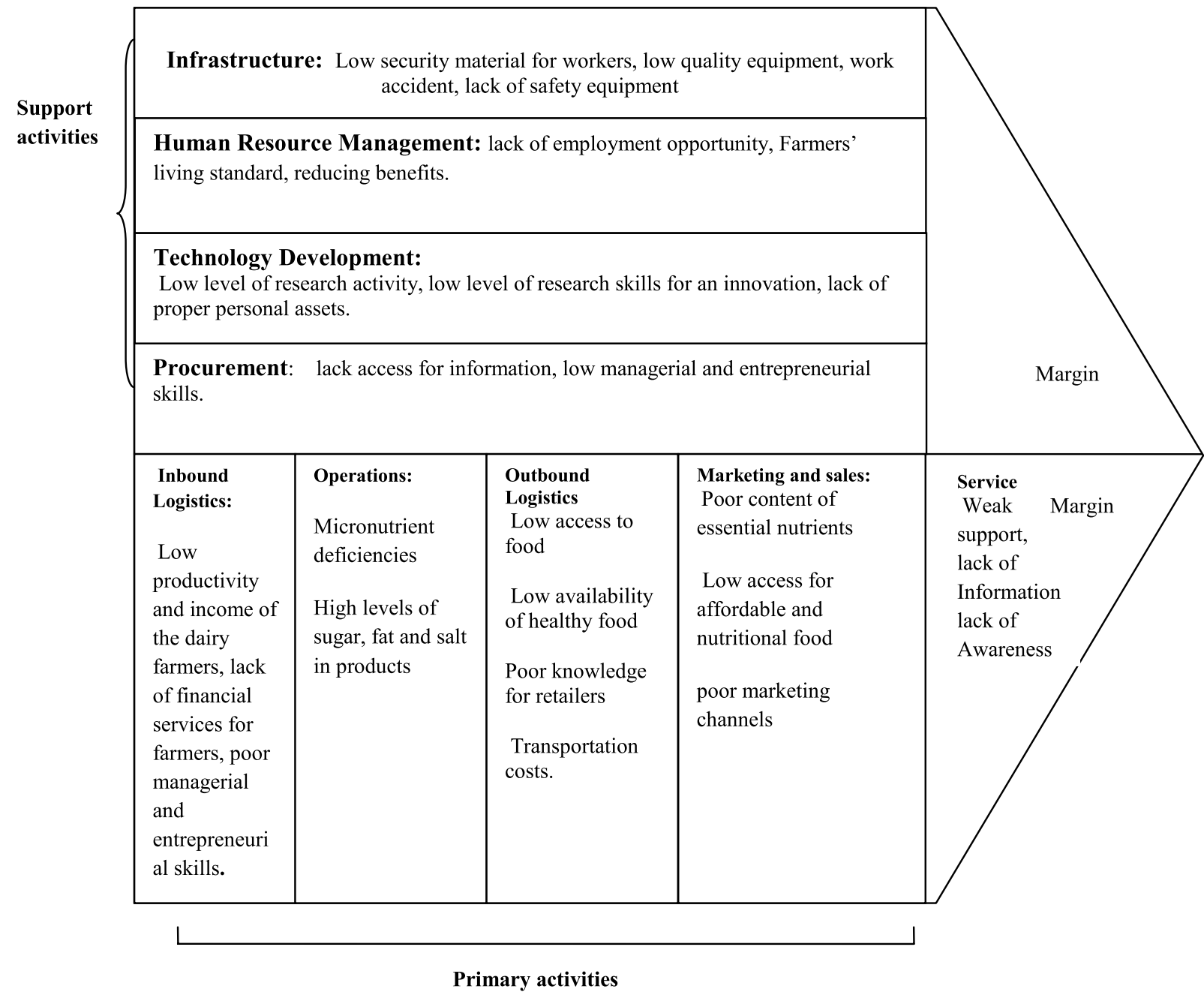

Source: Adapted from porter (1985).

7-2- Identifying environmental issues in food value chain:

There are a lot of environmental problems within food value chain, if food companies address these environmental problems; there will be great chance to achieve business value and environmental value as we see in figure2.

7-2-1- Primary activities:

In-bound logistics: within inbound logistics, we could find some environmental issues that need to be addressed such as: water pollution, high level of fuel consumption, pollution generated in transport mode, pesticide toxicity and long-term chronic illness, emissions from agricultural production, low level of returnable containers for farmers, few supplier ISO 14000 certified.

Operations: within operations; we could identify some environmental issues such as: lack of sustainable production practices (rainwater and watershed management and soil health Management), high level of amount of waste generated, hazardous material, depletion of resources, high use of energy for food production. 
Figure 2. Identifying environmental issues in food value chain

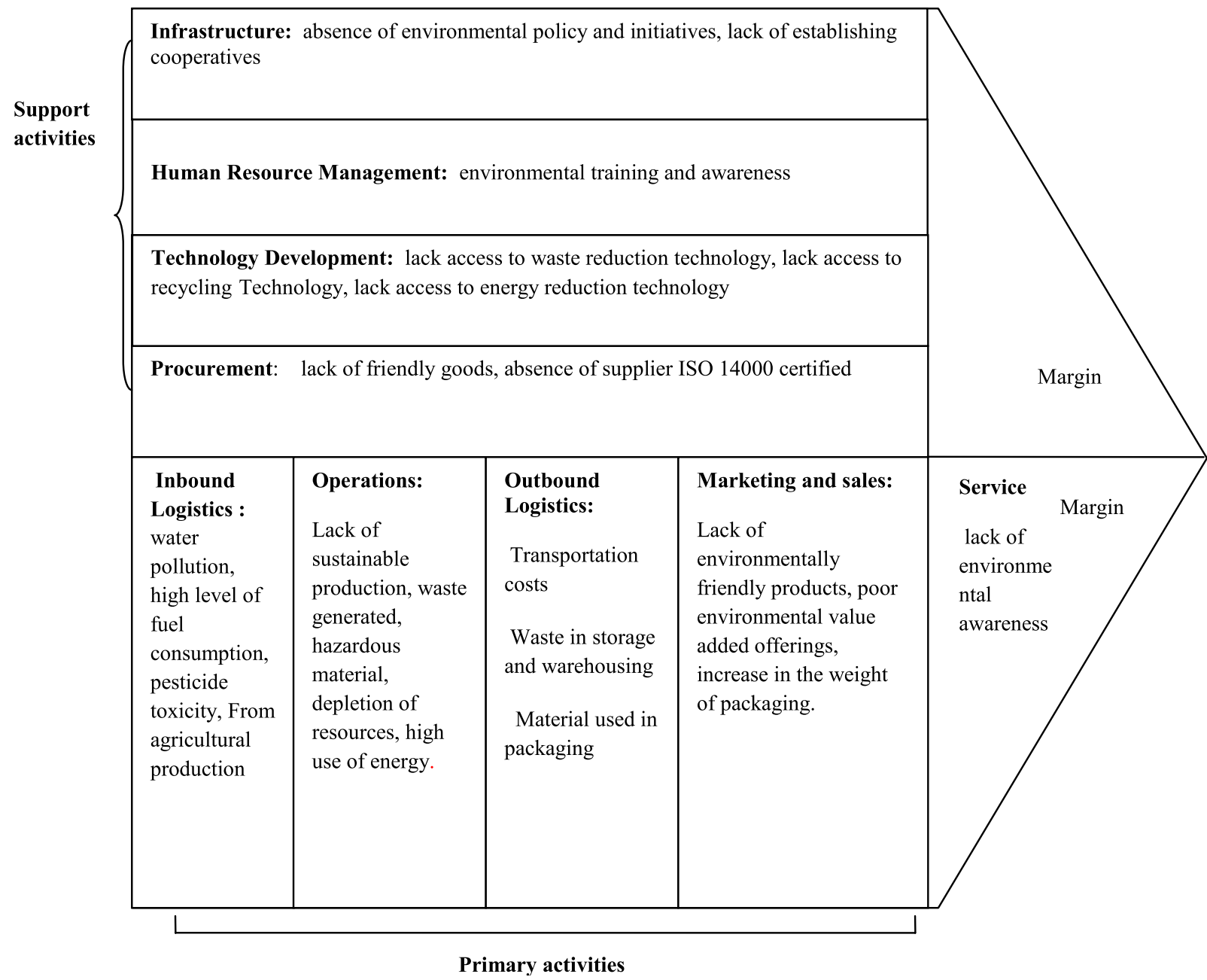

Source: Adapted from porter (1985).

In a study carried out with 13 companies in East Anglia, UK, it was found that annual savings of $1.1 \mathrm{~m}$ euro could be realized by reducing the use of raw materials, energy, water and waste generation (J N SELLAHEWA and W MARTINDALE2, 2010).

Outbound logistics: within output logistics; we could identify some environmental issues such as: transportation costs, waste in storage and warehousing, material used in packaging, packaging recyclable, poor roads and infrastructure.

Marketing and Sales: within marketing and sales; we could identify some environmental issues such as: lack of environmentally friendly products, poor environmental value added offerings, increase in the weight of packaging.

Service: lack of environmental awareness, poor environmental information provided for customers. 7-2-2- Secondary activities:

Procurement: within this activity, we can identify some environmental issues in food value chain such as; lack of friendly goods, absence of supplier ISO 14000 certified.

Human resource Development: such as environmental training and awareness.

Technological development: such as: lack access to waste reduction technology, lack access to recycling Technology, lack access to energy reduction technology.

Infrastructure: such as: absence of environmental policy and initiatives, lack of establishing cooperatives. 


\section{CREATING SHARED VALUE IN VALUE CHAIN}

Food industry impact start from effecting the environment using chemicals and also end harming environment by its outputs. We suggest that food companies may turn these social problems and issues from threats into business opportunities to achieve growth, by using the concept of shared value creation following the three pillars of reconceiving product and market, redefining the productivity in the value chain, enabling local cluster development as we see in table2.

Table 2. Social issues within value chain and shared value solutions.

\begin{tabular}{|c|c|}
\hline Social issues within value chain & Level of shared value for problem solving \\
\hline $\begin{array}{l}\text { Inbound Logistics: low productivity and income } \\
\text { of the dairy farmers, lack of financial services for } \\
\text { farmers poor managerial and entrepreneurial skills. }\end{array}$ & $\begin{array}{l}\text { Redefining the productivity in the value chain: by } \\
\text { empowering farmers through a sec of initiatives to improve } \\
\text { their yields }\end{array}$ \\
\hline $\begin{array}{l}\text { Operations: } \\
\text { micronutrient deficiencies } \\
\text { high levels of sugar, fat and salt in products }\end{array}$ & $\begin{array}{l}\text { Reconcieving products and markets: by using innovation in } \\
\text { research and development to make the products healthier } \\
\text { adding nutritional value }\end{array}$ \\
\hline $\begin{array}{l}\text { Outbound Logistics: low access to food, low } \\
\text { availability of healthy food, poor knowledge for } \\
\text { retailers, transportation costs. }\end{array}$ & $\begin{array}{l}\text { Enabling local cluster development: by improving } \\
\text { distribution, partnership with universities to train retailers, } \\
\text { using low cost transportation with high level of security. }\end{array}$ \\
\hline $\begin{array}{l}\text { Marketing and sales: } \\
\text { poor content of essential nutrients } \\
\text { low access for affordable and nutritional food } \\
\text { poor marketing channels }\end{array}$ & $\begin{array}{l}\text { Enabling local cluster development: partnership with } \\
\text { distributors and opening new marketing channels. }\end{array}$ \\
\hline $\begin{array}{l}\text { Service } \\
\text { weak support, lack of Information, lack of } \\
\text { Awareness }\end{array}$ & $\begin{array}{l}\text { Redefining the productivity in the value chain: by providing } \\
\text { supporting service for smallholders. } \\
\text { Enabling local cluster development by collaborating with } \\
\text { stakeholders to provide information to consumers and } \\
\text { awareness of food nutritive value and eating practices. }\end{array}$ \\
\hline $\begin{array}{l}\text { Infrastructure: } \\
\text { low security material for workers, low quality } \\
\text { equipment, work accident, lack of safety equipment }\end{array}$ & $\begin{array}{l}\text { Redefining the productivity in the value chain: by } \\
\text { providing high safety equipment, safe and secure working } \\
\text { environment. }\end{array}$ \\
\hline $\begin{array}{l}\text { Human Resource Management: lack of employment } \\
\text { opportunity, Farmers' living standard, reducing } \\
\text { benefits. }\end{array}$ & $\begin{array}{l}\text { Redefining the productivity in the value chain: by providing } \\
\text { jobs for potential smallholder farmers, improve their lives by } \\
\text { improving their incomes. }\end{array}$ \\
\hline $\begin{array}{l}\text { Technology Development: } \\
\text { low level of research activity, low level of research } \\
\text { skills for an innovation, lack of proper personal } \\
\text { assets. }\end{array}$ & $\begin{array}{l}\text { Enabling local cluster development by collaborating with } \\
\text { high tech companies and universities. }\end{array}$ \\
\hline $\begin{array}{l}\text { Procurement: lack access for information, low } \\
\text { managerial and entrepreneurial skills. }\end{array}$ & $\begin{array}{l}\text { Redefining the productivity in the value chain: by } \\
\text { empowering employees through training. }\end{array}$ \\
\hline
\end{tabular}

Source: Authors (2019). 
We also suggest that food companies may turn the environmental issues analyzed above from threats into business opportunities to achieve growth, by using the concept of shared value creation following the three pillars of reconceiving product and market, redefining the productivity in the value chain, enabling local cluster development as we see in table3.

Table 3. Environmental issues within value chain and shared value solutions.

\begin{tabular}{|c|c|}
\hline thin value chain & Level of shared value for problem solving \\
\hline $\begin{array}{l}\text { Inbound logistics: water pollution, high level of fuel } \\
\text { consumption, pesticide toxicity, From agricultural } \\
\text { production. }\end{array}$ & $\begin{array}{l}\text { Reconcieving products and markets by using innovation to } \\
\text { provide friendly product with low level of fuel consumption, } \\
\text { pollution, pesticide toxicity. }\end{array}$ \\
\hline $\begin{array}{l}\text { Operations: } \\
\text { lack of sustainable production, waste generated, } \\
\text { hazardous material, depletion of resources, high use } \\
\text { of energy. }\end{array}$ & $\begin{array}{l}\text { Redefining the productivity in the value chain by adapting } \\
\text { new practices and techniques that save resources to save } \\
\text { money and protect the environment. }\end{array}$ \\
\hline $\begin{array}{l}\text { Outbound Logistics: } \\
\text { Transportation costs waste in storage and } \\
\text { warehousing material used in packaging. }\end{array}$ & $\begin{array}{l}\text { Redefining the productivity in the value chain by reducing } \\
\text { waste in storage and warehousing and material used in } \\
\text { packaging. } \\
\text { Enabling local cluster development by collaborating with } \\
\text { distributers to find new distribution channels to reduce } \\
\text { transportations cost. }\end{array}$ \\
\hline $\begin{array}{l}\text { Marketing and sales: } \\
\text { Lack of environmentally friendly products, poor } \\
\text { environmental value added offerings, increase in } \\
\text { the weight of packaging. }\end{array}$ & $\begin{array}{l}\text { Recc } \\
\text { prov }\end{array}$ \\
\hline $\begin{array}{l}\text { Technology Development: lack access to waste } \\
\text { reduction technology, lack access to recycling } \\
\text { Technology, lack access to energy reduction } \\
\text { technology }\end{array}$ & $\begin{array}{l}\text { Enablir } \\
\text { univers }\end{array}$ \\
\hline $\begin{array}{l}\text { Human Resource Management: environmental } \\
\text { training and awareness }\end{array}$ & $\begin{array}{l}\text { Enabling local clusters development by working with labor } \\
\text { associations and environment associations to provide } \\
\text { environmental training and awareness for employees. }\end{array}$ \\
\hline $\begin{array}{l}\text { afrastructure: abse } \\
\text { nd initiatives, lack of }\end{array}$ & $\begin{array}{l}\text { Enabling local clusters development by collaborating with } \\
\text { government, provide sector, NGO's to adopt environmental } \\
\text { policy and initiatives. }\end{array}$ \\
\hline
\end{tabular}

Source: Authors (2019).

\section{CONCLUSION}

This paper makes a number of significant theoretical contributions to the literature. First, we make useful analyses by identifying most environmental and social problems food company would face within food value chain. Second, this study demonstrates why shared value is useful in identifying and solving environmental and social issues.

In addition, we make a number of empirical contributions; food companies could identify easily the environmental and social problems within the value chain, we analyzed every possible problem or issue in every single activity in the value chain, in addition to that we provided the shared value concept to solve most issues in the value chain through three main pillars; reconceiving products and markets, redefining the productivity in the value chain, enabling local cluster development.

Our work clearly has some limitations; we only use the concept of shared value creation to identify main social and environmental issues and solutions for food companies within the value chain, we need more research that use other concept to identify social and environmental issues, in addition to that these issues are only related with the value chain, other research need to investigate 
environmental and social issues on the industry and macro level.

The present findings have important implications for solving main social and environmental issues, this overview may help and give ideas to owners and managers of food companies to rethink their overall value chain by detecting environmental and social issues and used shared value concept to turn these environmental and social issues into a business opportunity. We hope that our research will serve as a base for future studies on identifying social and environmental issues and solutions, however further work needs to study these issues and differentiate social issues from environmental issues, in addition to that; researchers need to study these issues on the industry and macro level.

\section{REFERENCES}

Beretta, C., Stoessel, F, Baier, U, Hellweg, S. (2013): Quantifying food losses and the potential for reduction in Switzerland. Waste Management (3):764-773

Bolanle Deborah Motilewa, E.K. Rowland Worlu, Agboola.G.M, Gberevbie.M.A.C ( 2016):Creating Shared Value: A Paradigm Shift from Corporate Social Responsibility to Creating Shared Value, World Academy of Science, Engineering and Technology International Journal of Economics and Management Engineering Vol:10, No:8,pp 2687-2692.

Bourguet D, Guillemaud T (2016): The hidden and external costs of pesticide use. Sustainable Agriculture

Reviews: Springer. : 35-120.

Dabady.K, Tulk.P (2015): AGROCHEMICALS AND THEIR IMPACT ON HUMAN HEALTH An analysis of pesticide use and incidences of diseases in the region of Rincón de Santa María, ENVR 451: Research in Panama - Final Report, McGill University, p6.

Diamond, Adam, Debra Tropp, James Barham, Michelle Frain Muldoon, Stacia Kiraly, and Patty Cantrell (2014): Food Value Chains: Creating Shared Value to Enhance Marketing Success. U.S. Dept. of Agriculture, Agricultural Marketing Service, May 2014. Web. http://dx.doi.org/10.9752/ MS141.05-2014.

FAO, IFAD, UNICEF, WFP and WHO (2017): The State of Food Security and Nutrition in the World. Building resilience for peace and food security. Rome, FAO.

Giovannucci.D, Scherr.S, Nierenberg.D, Hebebrand.C, Shapiro.J, Milder.J, Wheeler.K (2012): Food and Agriculture: the future of sustainability. A strategic input to the Sustainable Development in the 21st Century (SD21) project. New York: United Nations Department of Economic and Social Affairs, Division for Sustainable Development.

Godfray HCJ, Beddington JR, Crute IR et al. (2010) Food security: the challenge of feeding 9 billion people. Science (New York, N.Y.), 327, 812-818.

Ilmarinen.P (2017): Creating shared value in Banking Case Savings Bank Group, doctoral thesis, School of Business JAMK University of Applied Sciences, p35.

J N SELLAHEWA and W MARTINDALE2 (2010): The impact of food processing on the sustainability of the food supply chain, Aspects of Applied Biology 102,p 94.

Kraemer, K.Cordaro, J.B.Fanzo, J, Gibney, M, Kennedy, E, Labrique, A, Steffen, J. (2016): Good Nutrition: Perspectives for the 21st Century, Eggersdorfer, M. (Kaiseraugst) , p46.

L.F. Henriksen, L. Riisgaard, S. Ponte, F. Hartwich, P. Kormawa ( 2010): Agro-Food Value Chain Interventions in Asia A review and analysis of case studies, United Nations Industrial Development Organization. usa, p10.

Meybeck.A Redfern.S (2016): Sustainable value chains for sustainable food systems A workshop of the FAO/UNEP Programme on Sustainable Food Systems, FOOD AND AGRICULTURE ORGANIZATION OF THE UNITED NATIONS, Rome, p128. ISBN 978-92-5-109532-4

Maestre.M.A, Poole.N.B, Henson.S.C (2017):Assessing food value chain pathways, linkages and impacts for better nutrition of vulnerable groups, Food Policy 68 (2017) 31-39.

ÖNDER.M, CEYHAN.E, KAHRAMAN.A (2011): Effects of Agricultural Practices on Environment, 
International Conference on Biology, Environment and Chemistry, IPCBEE vol.24 IACSIT Press, Singapoore, $\mathrm{p} 1$.

Panwar.R, Hansen.E.N (2009): A process for identifying social and environmental issues: a case of the US forest products manufacturing industry, J. Public Affairs 9: 323-336.

Preston.P (2017): What Is Shared Value And How Does It Help Me?, Shared Value Expert, First Edition, p4.

UNEP (2016) Food Systems and Natural Resources. A Report of the Working Group on Food Systems of the International Resource Panel.

Ranganathan, J.(1998): Sustainability Rulers: Measuring Corporate Environmental and Social Performance. Sustainability Enterprise Perspective, May, 1-11. Washington.

Riisgaard.L, Bolwig.S, Ponte.S, Toit.A, Halberg.N, Frank Matose.F (2010): Integrating Poverty and Environmental Concerns into Value-Chain Analysis: A Strategic Framework and Practical Guide. Development Policy Review, 2010, 28 (2): 195-216.

Revision of World Population Prospects 2010):. U.N. Population Division of the Department of Economic and Social Affairs.

Sagasta.J.M, Zadeh .S.M, Turral.H (2017): Executive summary: Water pollution from agriculture: a global review, The food and agriculture organization of the united nations and the International Water Management Institute on behalf of the Water Land and Ecosystems research program, p2. Torres, C., J. van Seters. 2016. Overview of trade and barriers to trade in West Africa: Insights in political economy dynamics, with particular focus on agricultural and food trade. Discussion Paper 195. Maastricht: ECDPM.

World health organisation (2018): Malnutrition Key facts, https://www.who.int/news-room/factsheets/detail/malnutrition, 28/04/2019. 